\title{
A DECONSTRUCTION OF THE MAHABHARATA: WHEN DRAUPADI WRITES BACK
}

\author{
ANA GARCÍA-ARROYO \\ Universidad de Valencia \\ garciaarroyo7@gmail.com
}

\section{Abstract}

From a post-colonial and gender perspective I examine R.K. Narayan's The Mahabharata (1978), Chitra Banerjee Divakaruni's The Palace of Illusions (2008) and Mahasweta Devi's "Draupadi" (1997), in order to analyze how they have rewritten the ancient myth of the Mahabharata. To be more precise, I look into the story of Draupadi, one of the most popular female protagonists, who has become an archetype of the Hindu woman. The ultimate goal is to demonstrate by confronting these narrations that Narayan's modern prose responds to the dominant Brahmanical discourse that has built up essentialist models of masculinity and femininity. In contrast, Divakaruni's and Devi's texts go a step further and 1) hark back to a Brahmanical patriarchy that has exercised control over the feminine throughout history; 2) offer a form of counter discourse by interrogating and deconstructing gender; 3 ) expose with their rebellious voices the limits of the colonizing power and 4) give us a more accurate understanding of women's realities in contemporary India.

Keywords: Mahabharata, Draupadi, Narayan, Divakaruni, Devi, gender and post-colonialism. 


\section{Resumen}

Desde la perspectiva de los estudios postcoloniales y de género, examino The Mababharata (1978) de R.K. Nayaran, The Palace of Illusions (2008) de Chitra Banerjee Divakaruni y "Draupadi" (1997) de Mahasweta Devi, con el fin de analizar críticamente cómo estos autores han re-escrito el mito épico antiguo del Mahabharata. De forma más precisa me concentro en la historia de Draupadi, uno de los personajes femeninos más famosos, que se ha convertido en un arquetipo de mujer hindú. Al confrontar estas narraciones el objetivo principal es demostrar que la versión moderna en prosa de Narayan responde al discurso dominante Brahmánico que ha construido modelos esencialistas de masculinidad y feminidad. En su lugar, los textos de Divakaruni y de Devi se alejan de esto y l) desafían y se resisten al patriarcado Brahmánico que ha ejercido control sobre lo femenino a través de la historia; 2) ofrecen un contra-discurso con su interrogación y deconstrucción del género; 3 ) exponen los límites del poder colonizador con sus voces contestatarias y 4) nos ofrecen un conocimiento más preciso sobre las realidades de la mujer en la India contemporánea.

Palabras clave: Mahabharata, Draupadi, Narayan, Divakaruni, Devi, género y postcolonialismo.

\section{Introduction and Aims}

Men and women in India know that the structure upon which contemporary Indian society rests has its origins in ancient India. All Indians are brought up with a sense of the past that they incorporate through the transmission of popular culture, traditions, mythology and folklore. These particular features constitute an important part of their history and identity. One of these components that has enormously marked Hindu consciousness throughout the ages is the epic myth of the Mahabharata which in modern times has been re-written and re-adapted in multifaceted narrations and from many different perspectives. There are Indian English writers like R.K. Narayan with The Mahabharata (1978) and Shashi Tharoor with The Great Indian Novel (1989) who opt to maintain the imposing tone of the masculine voice of the epic text and its patriarchal context, although their retellings distinctly differ from each other. Whereas Narayan relates a shortened modern prose version of the epic, Tharoor writes a satirical novel that takes the story of the Hindu myth and resets it in the context of the Indian Independence movement and the first decades after 1947. The mythic story is then transformed into a historical depiction of events and political figures. On the other hand, there are also female writers like Chitra Banerjee Divakaruni with her 
novel The Palace of Illusions (2008) and Mahasweta Devi with her short story, "Draupadi" (1997) —compiled in the collection Breast Stories (2010)—, who rewrite the Hindu epic from the point of view of Draupadi, the courageous protagonist, in order to bring the politics of domination into relief, as this paper will examine.

This article aims to study, from a post-colonial and gender studies perspective, how different contemporary Indian writers have re-written the ancient epic text, the Mababharata, from very different approaches. Firstly I will analyze the work by one of the pioneers in Indian English writing, R.K. Narayan and his novelized version, The Mahabharata (2004, first published in 1978), which contains the key elements that hold together the main story of the ancient text. The purpose is to demonstrate that Narayan's faithful narration and viewpoint of the main events respond to the dominant Brahmanical discourse that has built up essentialist models of masculinity and femininity. To be more precise, I will look into the episode of Draupadi, one of the most popular female protagonists, who has become a model of womanhood. Secondly I will examine Chitra Banerjee Divakaruni's The Palace of Illusions (2008) and Mahasweta Devi's short story "Draupadi" (2010), who re-write the myth of the Mababharata from a female perspective, that of Draupadi, to question Brahmanical discourse and the construction of an archetypal Hindu woman.

The ultimate goal is to demonstrate by confronting these narrations that Divarakuni and Devi go well beyond Nayaran's re-writing of the ancient epic, and take the myth a step further. They 1) respond - or write back - to Brahminical patriarchy that has exercised control over the feminine throughout history; 2) They offer a form of counter discourse by interrogating and deconstructing gender essentialisms and hegemonic power; 3 ) They expose the limits and absurdities of the dominant discourse with their subversive voices, and 4) They give us a more accurate understanding of woman's realities in contemporary India.

\section{The Ancient Myth of the Mahabharata: A Patriarchal Text}

To begin with and to situate the reader in the context of the epic the Mababharata, which is fundamental to an understanding of the way contemporary writers have re-set and re-written this ancient myth, I will briefly list the major characteristics. ${ }^{1}$ the Mababharata is one of the most highly praised texts of Indian culture. It offers multiple readings from different perspectives, which particularly highlight its historical, mythological, philosophical and religious values (Radhakrishnan 1989). It is a long poetic narrative in eighteen volumes, composed in Sanskrit and 
written between $300 \mathrm{BCE}$ and $500 \mathrm{CE}$, although the history of events narrated go back to around $1000 \mathrm{BCE}$, when the different nomadic tribes, the Aryans, came to India and gradually settled down in the fertile lands of the Ganges and the Yamuna, abandoning their nomadic life style and developing the agricultural skills that were available at that time. The text reflects a very complex society made up of a great diversity of tribes with different customs, and different models of the family. This is not the place to analyse these family models due to the length and complexity of the topic and the fact that it would distract from the matter in hand. However, I would like to point out that throughout history Brahmanic patriarchy has committed itself to the perpetuation of a single archetype of Indian family, the extended or joint family, in detriment of other more varied family units that also appear in the ancient text. The main purpose of prioritizing the extended family as a hegemonic model of family structure, down through the centuries, has been no other than to exercise control over women and the lowest castes through the imposition of a series of laws, traditions, texts, customs and limits (Chakravarti 2007), as I will demonstrate when the key pillars that hold the main story of the Mababharata are analyzed. In fact the major plot can easily be summarized for it simply deals with the fratricidal struggle between members of the same family: on the one hand are the Kauravas, also called the one hundred sons of the old blind king, Dhritarastra; and on the other hand we have their cousins, the five Pandava brothers. Both parties, Kauravas and Pandavas, face each other in an inevitable battle for the succession to the throne and the control of the kingdom and the subjects.

Philosophically, we can read the Mahabharata as a profound manifestation that narrates the eternal story of mankind, the constant struggle for power and dominance, in which Lord Krishna also appears in order to save human souls. Nevertheless, if we examine the Mababharata from the point of view of gender studies it is clear that, despite its magnificence in religious, philosophical, historical and literary values, the Mababharata is, par excellence, a patriarchal story. Moreover, it is composed in that period of history that has left behind the age of matriarchal cultures, ${ }^{2}$ metals like tin, bronze and iron have been discovered, agriculture has appeared and starts flourishing and as a result the land becomes very valuable and needs more and more labour. It was then that the Aryans abandoned their nomadism and settled down in the fertile lands of the Ganges and the Yamuna. All these historical events led to the struggle for the control of the land, the exercise of power and the subjection of some beings over others, as Simone de Beauvoir shows in The Second Sex (1949), explaining the origins of patriarchal societies and how they developed. Private property was created at that time, Beauvoir contends in the third chapter, and with it came the exploitation of people by their fellow human beings. Around this time too a dense literature of 
myths emerged where the protagonists are the male heroes and the women passively support the men warriors, as in the first chapter of Narayan's The Mahabharata where Kunthi and Madri, mothers of the five Pandava brothers, invoke the gods and pray to get pregnant by the divine seed and bear boys who will become good warriors and fight and defend the land. It is noteworthy that the Mababharata prioritizes high caste families such as the warriors ('ksatriya'), in which each member occupies a particular position in the family hierarchy of the extended family and must resolve the moral dilemmas and conflicts according to his/her place (Chakravarti 2007).

\subsection{Draupadi: The Sublimation of Suffering}

I would now like to focus on Draupadi, a figure that has built a very specific image of womanhood, that of the suffering and obedient Hindu woman, which has deeply conditioned popular consciousness. Paradoxically, the Mahabharata narrates that Draupadi has defied the local law and customs by marrying the five Pandavas, a very reprehensible conduct and in no way permissible in those days, as described in chapter four "Bride for Five" (Narayan 2004). But what are the main facts of the story that lead Draupadi to challenge the established norms of the patriarchal Aryan-Hindu society? And why has she been considered a prototype of the Hindu woman?

In Narayan's The Mababharata we are told that Draupadi is a beautiful and intelligent young princess who lives in the kingdom of Panchala. When the time comes her father, the king, announces her 'swayamvara', which is a competition where the warrior that wins marries the princess. The test is prepared and consists of testing the warrior's skill in the use of a heavy bow and arrows. Arjuna, one of the five Pandava brothers, is the only one capable of meeting this challenge and Draupadi proclaims him the winner and accepts him as her husband. After the victory, the Pandavas lead Draupadi to their home in the forest where they live with their mother Kunthi. She does not notice who is with them and automatically tells Arjuna to share his trophy with his brothers. When Kunthi discovers her mistake, she does not retract her order and allows Draupadi to be the wife of the five Pandavas.

The story tells us that after some time the enemy, the Kauravas, in their eagerness to seize the throne and get control of the kingdom of Bharata, ${ }^{3}$ have started to conspire against the Pandavas. The Kauravas invite them to play dice, a very popular game in those days, because they know that Yudhisthira, the eldest brother, is fond of the game and it will be easy to play a trick on him: "Yudhisthira slipped into a gambler's frenzy, blind to consequences, his vision blurred to all but the ivory-white dice and the chequered board. He forgot who he was, where he was, 


\section{Ana García-Arroyo}

who else was there and what was right or wrong" (Narayan 2004: 56). Having lost his material possessions he stakes his brothers and loses them. Then he stakes himself and loses again. Finally he also puts Draupadi up as a bet and loses his wife too. Draupadi is horrified to hear this and refuses to go to court. She also tells them that she is having her monthly period and not appropriately dressed to appear before the royal assembly of men but her objections are ineffectual. Although she is clothed in a simple garment one of the Kauravas grabs her hair and forcefully pulls her in. There they humiliate her, arguing that a woman with five husbands is a whore. To punish her for breaking the laws of honour, she is ordered to be disrobed, which is one of the most humiliating expressions of sexual harassment a Hindu woman can suffer. ${ }^{4}$ Draupadi's husbands remain passive so she prays to her God, Krishna, to protect her. A miracle happens when one of the Kauravas starts unwinding yards and yards of her sari and it becomes endless. At this point everybody looks on in awe and eventually Draupadi begs the old blind king of the Kauravas, Dhritarastra, to release her five husbands. The king satisfies her desire and the Pandavas and Draupadi return to their house in the forest. This is the story about Draupadi that the majority of Indians would tell today; an emblematic narration that has been transmitted from generation to generation (Sharma 2007). My purpose is to analyze how this story has been interpreted and how it has influenced and conditioned popular thinking in contemporary India.

Different critics and scholars such as Gayatri C. Spivak in In Other Worlds (1987) argue that Draupadi is a courageous woman who bravely breaks the strict gender barriers by defying the law and custom of her time: she can be proud -if she wishes - of having sexual relations with her five husbands. However, patriarchal cultural patterns, constructed by Brahmanical ideology, are so integrated into the minds of the majority of Hindus that far from seeing Draupadi as an assertive woman, it is the constant humiliation she receives that is praised; in other words, instead of becoming a heroine her victimhood is highlighted. In this way the patriarchal hegemonic gaze makes Draupadi an extraordinary woman for the humiliation and mockery she accepts. Thus Draupadi represents an extraordinary model of the sublimation of suffering and oppression that for a large part of Hindu popular consciousness needs to be victorious. Other specific examples of this sublimation would be the following: first, Draupadi is a princess but she is treated as an ordinary woman because she has to undergo the ritual of the 'swayamvara' in which she is the trophy; second, the five Pandavas have to share Draupadi and what worries her is whether she will be able to serve them well; third, she is humiliated and treated like a prostitute for violating the moral laws and social conventions, punishments which her husbands do not have to undergo, nor are they condemned to be naked in public; and fourth, even the mother, Kunthi, has subtly internalized these fixed gender norms that sustain these extended high caste 
families and it is very difficult for her to take her word back; she does nothing to save Draupadi from becoming the sex object of her five husbands and their faithful servant. It has to be underlined then that Brahmanic ideology has always praised this traditional image of womanhood in which humiliation becomes a heroic pattern. The constant repetition of this myth and the exaltation of Draupadi in particular, a woman who endures suffering, has given rise to the construction of fixed cultural binaries of femininity and also of masculinity; of brave male warriors and suffering women.

\section{When Draupadi Writes Back}

The grandeur of the literary art allows us to analyze, re-create and re-tell stories from different perspectives that deconstruct hegemonic positions. Gayatri Spivak (1987) and Uma Chakravarti (2003 and 2007) fight against the patriarchal discourse of the Mababharata, also in contemporary narrations like Narayan's, which due to Brahmanic influence have become rigorous exponents of orthodoxy and authenticity of Hindu culture. In addition, other contemporary writers like Chitra Banerjee Divakaruni and Mahasweta Devi re-write the Mababharata from the perspective of Draupadi, putting the emphasis on 'the feminine', stressing sensitivity and responding to the hegemonic power of Brahmanism, which through the official history of colonization has attributed to the feminine a considerable degree of passivity and weakness.

\subsection{Questioning of the Mahabharata: Chitra B. Divakaruni's Contemporary Re-Telling}

In The Palace of Illusions (2008) Divakaruni gives voice to the princess of Panchali, another name that is also used for Draupadi, who tells her own story and writes back to patriarchy. The novel of Divakaruni more faithfully represents an example of today's modern woman in India, whose reality is not easy but who takes control of her own life and constantly struggles against barbaric traditions, selfish interests, lack of ethics and local and global conflicts. In her role of storyteller, Divakaruni's Draupadi exercises the unremitting function of questioning every single word that sustains patriarchal power. From the very first page Draupadi carries out her incisive work, interrogating the practices and values of masculine society. She questions every character that appears and, for example, speaks openly of her sexual desires, confessing that although she is a good wife she does not love her husbands. The narration of her story throws light on those dark areas of a woman who has to live in a masculine world. Let us consider some of the many examples in the novel that show the nonstop action of the protagonist in questioning everything. 
Right at the start Draupadi complains about her name; how is it possible - she asks us - that her brother was given a name that means 'destroyer of the enemy' and she was just called 'the daughter of Drupad'?: “Couldn't my father have come up with something a little less egoistic? Something more suited to a girl who was supposed to change history?" (Divakaruni 2008: 5 ). We also find at the beginning of the narration that according to the prophecy proclaimed by the priests at her birth the daughter of Drupad is destined to change the course of history. When hearing this news, Draupadi is surprised and questions whether this is possible because her name, the daughter of, already indicates a subordinate position and she asks whether she has been given the corresponding attributes that correspond to a heroine who is destined to intervene in the process of history such as courage, perseverance and an iron will. It seems that the author is pointing to the fact that her heroine, Draupadi, will be very different from Narayan's and also from the one in the ancient epic, because she will be the maker of her own life, responsible for conducting it, instead of silently following the norms dictated by others. Moreover, her actions will have repercussions in the twists and turns of her story and will transform the dark reality around her. We can deduce that Divakaruni's heroine's main purpose is to deconstruct the ideal of passivity and female submission and offer a stark contrast to the patriarchal 'Mahabharatas'. At the same time her figure shows a different model of woman, one who is an active agent, eager to shape her own life, which is more in consonance with contemporary times and current realities. With this same purpose Draupadi continues questioning the duty that tradition has assigned to her, a woman born into a high-caste:

A kshatriya woman's highest purpose in life is to support the warriors in her life: her father, brother, husband, and sons [...]

"And who decided that a woman's highest purpose was to support men?" (2008: 26)

Draupadi belongs to the warriors' caste but she does not understand why men are always battling. She even considers that if they want to be crowned with glory there are other ways, which she intends to teach them if they like. Consequently, we find ourselves before a Draupadi who embodies very noble human values; a heroine that truly embraces the feminine, in other words, a woman whose aim is to create harmony and peace and teach people to do the same by her example, instead of adopting an essentialist masculine pattern that would imply violence, competition, possession, categorization, subjugation or colonization of the other. ${ }^{5}$ A few pages later she expresses this idea: “The kings are always fighting', she said. 'All they want is more land, more power. They tax the common people to starvation and force them to fight in their armies"” (Divakaruni 2008: 65). 
Another example in which Draupadi vindicates a dignified feminine space has to do with the relationship established with her five husbands. In the patriarchal text she must spend one year with each one of them and every time she is passed into the hands of the next husband she is granted the gift of virginity. The heroine of Divakaruni interrogates this absurd arrangement because she feels like a jug of drink passing from hand to hand. She ironically questions the gift of her virginity and affirms that this particular present granted to women only seems to benefit men.

Little by little Draupadi learns that her husbands do not love her all that much: "there were other things they love more. Their notions of honor, of loyalty toward each other, of reputation were more important to them than my suffering" (Divakaruni 2008: 195). As she gradually discovers the subtle shades of dominant masculine power through her husbands and the men around her, it is not surprising that when Yudhisthira loses the palace playing dice, Draupadi shouts angrily in front of them: “My palace?' I interrupted furious. 'He had no right!"” (190). Naturally, Draupadi gets irritated and complains because her palace, the palace that gives the title to the novel, The Palace of Illusions, is a metaphor of her life, also of the lives of many women who have illusions. It symbolizes a woman's space, the room of one's own as Virginia Woolf would put it; a feminine space that continually has to be re-created and re-appropriated in order not to be colonized and dismantled in the battle against oppressive masculinity. "The laws of men would not save me" (191), Draupadi declares when they are about to strip off her sari. Then she asks her God, Krishna, for some help and adds: "Let them stare at my nakedness, I thought. Why should I care? They and not I should be ashamed for shattering the bounds of decency" (193).

This concept of decency to which Divakaruni's Draupadi alludes would correspond to the paradigm of ethics, tremendously necessary in today's world as Metka Zupančič argues:

In today's world ruled by self-absorbed individuals, with egotistic preoccupations that foster divisions, conflicts and separations [...] Divakaruni's prose writings, especially some of the most recent ones, carry profound ethical values and the promise of a world that we could all build together, with literature as an efficient and convincing tool for collective transformation based on mutual understanding and love as a binding force. (2013: 107)

Bearing in mind that the Mababharata tells the story of the beginnings of mankind, in these rapidly changing times the perspective of women is also quintessential and has to be represented fairly in local and global contexts where ethics should not be left out.

Therefore we can deduce that Divakaruni's novel intertwines the historical facts of a given period, along with magic and myth, while patriarchal values like violence, 


\section{Ana García-Arroyo}

aggressive competitiveness and the domination and submission of the feminine are deconstructed. An ancient story transmitted from generation to generation for thousands of years is re-written and narrated today by a woman who offers a more precise depiction of the reality of contemporary India, where human conflicts are seen in a new light and essentialist patterns of gender are also deconstructed. By adopting a narrative style of constant interrogation fruitful results are obtained: 1) Brahmanic patriarchal structures are challenged and deconstructed; 2) women are rescued from the shackles of a traditional oppressive culture; 3 ) the pattern of a submissive and subservient woman is undone; and 4) an alternative model of the feminine is shown. There is no doubt that Divakaruni's contemporary narration of the ancient myth, from the perspective of the princess of Panchali, or Draupadi, implies a courageous act of rebellion against Brahmanic tradition and the traditionalist Hindu mindset that advocates a static and unchanging Indian culture. Divakaruni's writing-back emphasizes the existence of other realities of women and shows how myths can be adapted to represent the realities of the times.

\subsection{Dopdi or the Power of an 'Adivasi' Woman}

Another postcolonial writer who has re-written the story of Draupadi is Mahasweta Devi with her short story, "Draupadi" (2010). ${ }^{6}$ Devi is a Bengali writer whose greatest concern and source of inspiration have always been the indigenous tribal populations of India or the adivasi, ${ }^{7}$ who have inhabited India since ancient times. Owing to (neo)colonization the adivasi people have always been in a very vulnerable position, which has encouraged Devi to portray the crude realities of their existence, especially of women. This is her description: "I find my people still groaning under hunger, landlessness, indebtedness, and bonded labour. An anger, luminous, burning and passionate, directed against a system that has failed to liberate my people from their horrible constraints, is the only source of inspiration for all my writing” (Goel 2007: 203).

"Draupadi" is a good example of the kind of social literature that Devi writes. Moreover we can read it in parallel with Narayan's patriarchal text. The story is composed of three parts. In the first one the protagonist, Draupadi, is introduced to the reader with the name of Dopdi, which is the tribalized form. Dopdi and her husband Dulna are wanted by the police because they have participated in a peasant's revolt which resulted in the death of a landowner. They are also accused of being the ringleaders of a group of ideologically-driven members of the tribe and intellectuals who have attacked various police headquarters and have killed various landowners, money-lenders and bureaucrats among others. Then Senanayak is introduced, the army officer who is responsible for putting down the revolts. Soon Dulna dies and the soldiers use his body as bait to capture Dopdi, 
but she does not fall into the trap and takes to the forest by way of escape. This first part concludes with an atmosphere of terror: the powerful of the place are terrified of being attacked by the rebels.

The second part focuses on the unceasing search for Dopdi; the narration underlines the description of her dilapidated appearance, badly undernourished: "with some rice knotted into her belt [...] as she walked, she picked out and killed the lice in her hair" (Devi 2010: 27). It also highlights her psychological state, she is tormented by what can happen to her if the soldiers capture her: "When they kounter you, your hands are tied behind you. All your bones are crushed, your sex is a terrible wound" (29, emphasis in original). We discover at this point what was the cause of the uprising by the adivasis, the peasants and certain intellectuals that has unleashed such a wave of violence: one of the landowners - the one assassinated - built several wells on his property, giving rise to a terrible drought in the region. This strategy seems to be very commonly used by the wealthy and the landowners to increase their rice production, resulting in the impoverishment of the peasants. Without basic resources the peasantry will feel obliged to borrow food or money from the masters in this vicious circle of a feudal system: "The quarrel began there. In the drought, human patience catches easily [...] Dulna had said, I'll have the first blow, brothers. My great-grandfather took a bit of paddy from him, and I still give him free labour to repay that debt” (2010: 30). Finally, the soldiers manage to hunt down Dopdi, who looks weak but still has enough energy and pride to launch a cry to heaven in favour of her adivasi people.

The third part of the story creates more intense feelings because it deals with the humiliation, torture and pain of the protagonist. Senanayak orders his soldiers to "do the needful" (Devi 2010: 35) and soon the rape starts: "Indeed, she's made up right. Her breasts are bitten raw, the nipples torn. How many? Four-five-sixseven - then Draupadi had passed out” (35). Her degradation is palpable but in the last scene the writer surprises us giving a relevant twist to the whole narration, as will be seen later.

Now that we know the story we can argue that the title "Draupadi", as well as the name of the main protagonist, is not a mere coincidence. On the contrary, Devi's aim is to re-write this chapter of the Mahabharata from a feminine perspective. In her introduction to Breast Stories (2010) Gayatri Spivak argues that "the ancient Draupadi is perhaps the most celebrated heroine of the Indian epic Mahabharata. The Mababharata and the Ramayana are the cultural credentials of the so-called Aryan civilization of India" (in Devi 2010: 10) and have marked Indian patriarchal culture until today.

In Devi's short story the name of the protagonist appears in two versions: the form 'Draupadi' is used for the title and in the third part of the story that takes place in 
Senanayak's space. The other version, 'Dopdi', corresponds to a more tribalized use of the name and is employed in the first and second part, within a more rural and natural context where she lives. We know that to name means to identify so in the tribalized version of her name the writer is pointing to Dopdi's origins; in other words, Devi wants to highlight the fact that she is an adivasi woman and consequently she will be exposed to a double humiliation. She does not mention her particular tribal group, although we can guess she is a Santal because they are the largest tribe in West Bengal. However, the writer's objective is not to underline Dopdi's ethnic belonging but rather to remind us of a piece of history, often forgotten, and emphasize the fact that the adivasis were already living all over India before the arrival of the Aryans around 2000 BCE. The Aryans crossed the Hindu Kush mountain range and gradually moved towards the fertile plains of the Ganges and the Yamuna. On their way they occupied vast territories, fought against their inhabitants, the adivasis, in long wars until the latter were killed or defeated (Keay 2000). One of these terrible, long wars is narrated in the myth of the Mababharata that glorifies the male heroes of the Aryan race. We then understand that with "Draupadi" Mahasweta Devi intends to shed some light on a historical episode and emphasize the subordinate position of the adivasi peoples, who were colonized and subjected by the Aryan hegemony. The Aryan colonizers introduced their Sanskrit language, their Vedic religious texts, their deities, their legal treatises like the Laws of Manu, their epics, the Mababharata and the Ramayana, ${ }^{8}$ and a whole series of moral values, cultural and social structures - like caste or the extended family - that have provided India with "an unprecedented cultural integrity and an enviably high degree of civilization” (Keay 2000: 22). And centuries later, Keay argues

out of the west came the British. No less fair, no less manly and no less confident of their superiority, they were the new-Aryans, galvanising a naturally lax people into endeavour and industry, showering them with the incomparable benefits of a higher civilization and a humane religion, and ushering in a new and golden age. Or so some liked to think. (2000: 22)

Likewise, the British also colonized India, subjected the population, imposed their culture and as a result Indians, in general, and also the most vulnerable populations like the adivasis, had to defend themselves from a new invader.

Mahasweta Devi's story metaphorically refers to this continuous colonization that has occurred throughout history in which her adivasi people ${ }^{9}$ have been oppressed. She puts the emphasis on the abuse of power and above all on the exercise of resistance. She highlights adivasi resistance to all kinds of colonizers, the Aryans, the English and also Senanayak, the police officer, who symbolizes the dominant power in contemporary India. With thorough conviction Devi remarks in 
"Draupadi": "He is Prospero as well" (2010:23), and she directs us to The Tempest by Shakespeare, where the colonizer, Prospero, has conquered Caliban's island and has made him his slave. In Post-Colonial Transformation (2001) Bill Ashcroft writes: "Prospero and Caliban and Prospero and Miranda can be seen to provide endlessly adaptable models for the relationship between empire and settlers, or between colonizers and indigenous inhabitants" (2001: 33). In addition, Devi stresses the significance of his name, 'Senanayak', which is not really his own but a common one meaning "chief of police", probably to underline what Spivak comments: "This may be a critique of the man's apparently self-adequate identity" (in Devi 2010: 16).

Undoubtedly Senanayak represents the official dominant power that serves and obeys the land owners who govern and control the production of the land; the same people who corrupt the laws leaving the region without water - as the story narrates - because they know that they will profit from it and be able to control the peasantry. The control of the land at the time of the ancient myth of The Mababharata and also in contemporary days appears to be fundamental and Mahasweta Devi with "Drapadi" is connecting both texts and re-writing the realities of the adivasis in general, and the women in particular, who continue struggling to maintain their rights. Vandana Shiva in Staying Alive: Women, Ecology and Development (1989) demonstrates that today some multinational companies have signed agreements with corrupt local Indian governments to extract water in unlimited amounts and non-sustainable ways, leaving dry the water resources of the poorest communities, mostly adivasi communities. Assertive adivasi women like Dopdi denounce these violations and mobilize in defence of their own land (Chakrabarty 2015).

As a result we learn that "Draupadi”, Devi's short story, interrelates different historical episodes of colonization, the Aryans vs. the adivasis; the British vs. the Indians; Senanayak vs. Dopdi, in a narrative scenario that transcends the boundaries of time and space. It is noteworthy that in the cultural encounter between the colonizer and the colonized, the most vulnerable, whether adivasis, Indians or Dopdi, have always given expression to their resistance. Then what does it mean to resist? What does resistance imply, we may ask as Bill Ashcroft does in Post-Colonial Transformation (2001). Ultimately, there are many ways of exercising resistance and the term itself adapts to many circumstances, if we consider that to resist is a mode of self-defence against an invader, a simple way of saying "no". Among the myriad expressions for offering resistance, Ashcroft states that "the subtle and sometimes even unspoken forms of social and cultural resistance have been much more common [... They] are most interesting because they are most difficult for imperial powers to combat" (2001: 20). This is what 
happens in the third part of "Draupadi", when the soldiers apprehend her. "Do the needful" (Devi 2010: 35), Senanayak orders, and they begin to rape her, as an example of punishment designed to reaffirm their authority. Draupadi is all covered in blood and has lost all hope: "Perhaps they have abandoned her. For the foxes to devour. But she hears the scrape of feet [...] Draupadi closes her eyes. She doesn't have to wait long. Again the process of making her begins. Goes on" (2010: 35). She is suffering the highest degradation a woman can bear and she does not invoke heavenly powers or the help of the gods, as the Draupadi in Narayan's narration does, accurately following the ancient myth. To save her reputation and honour in these patriarchal texts God Krishna appears and protects Draupadi's womanhood, miraculously giving her a sari with layers and layers of cloth that the enemy cannot unwrap. By contrast, Devi's Draupadi expresses her resistance to Senanayak and the colonizing power he represents, and tears off her bloody piece of cloth, then she bravely stands before the chief officer, all naked:

You asked them to make me up, don't you want to see how they made me? Where are her clothes?

Won't put them on, Sir. Tearing them. [...]

What's the use of clothes? [...] There isn't a man here that I should be ashamed [...] Come on, kounter me - come on-, kounter me-? (2010: 36-37, emphasis in original)

Faced with such a challenge, Senanayak is puzzled because he has possibly underestimated the power of a woman, an adivasi woman, who is alone and in such circumstances. Draupadi uses the term 'kounter' to allude to the ruthless and aberrant sexual encounter, the rape itself, and to her ultimate death. But with the appropriation of this same sexual discourse, using her body as a weapon, Draupadi emerges from her misery - as a colonized object — and transforms herself into a powerful subject capable of infusing fear into Senanayak, "for the first time Senanayak is afraid to stand before an unarmed target, terribly afraid" (37, emphasis in original), a marvellous narrative twist with which the author concludes the story and strikes a blow against the dominant power.

\section{Conclusion}

To conclude this paper I would like to stress that both Mahasweta Devi and Chitra Banerjee Divakaruni fabulously ${ }^{10}$ re-write the representation of the feminine, of Draupadi, and interrogate not only the myth of the ancient epic text, but also all the contemporary patriarchal narrations of the Mababbarata such as Narayan's. With their respective idiosyncrasies and narratives, the writers 
respond to Brahmanic tyranny and show us images of women and of the feminine, which are more in consonance with the diversity of India's contemporary realities. Their re-writing and also their writing back manage to 1) destabilize Brahmanical patriarchy; 2) subvert the models of representation of the dominant discourse with respect to the colonized subject and 3) stress —as Spivak (1987) puts it - that the subordinate cannot speak within the hegemonic discourse, which does not mean that $\mathrm{s} /$ he has no power or voice, as this paper has demonstrated. Within his/her otherness the colonized/subordinate/subaltern has constantly exercised and still exercises resistance to the dominant power. Last but not least I would like to underline that with their elegantly subversive narrations, Devi and Divakaruni recreate a very significant part of the myth of the Mahabharata, the chapter focused on the figure of Draupadi, and demonstrate that re-writing stories like this not only consists of adding one more voice or a different version or a radical position to the literary complexity, but also of taking the pulse of the same patriarchal colonizing discourse and displaying its limits and absurdities.

\section{Notes}

1 See also the English film adaptation of the Mahabharata, directed by Peter Brook in 1989, which is a TV mini-series of about 6 hours. In 1985 his original ninehour long stage play of the Mahabharata toured around the world.

2 See for example the myth of the Devi-Mahatmya narrated in Encountering the Goddess by Thomas B. Coburn (1992), which tells the story of Devi, the Great Divinity that reigns in the cosmos, who is worshipped by the first tribal populations of India that lived here before the arrival of the Aryans and are displaced by them.

3 'Bharata' in Sanskrit means India; and 'Maha' great. Consequently 'Mahabharata' means great India. However it is important to note that the context centres around the plains of the Ganges and Yamuna, that is to say, in today's India it corresponds to the area around Delhi and the state of Haryana. In fact the story mentions that the great battle between the Kauravas and the five Pandavas takes place in
Kurushetra, which has become a sacred city in the state of Haryana.

${ }^{4}$ Being forced to walk naked is a severe punishment in India, used even today. There are many examples in the press like, "India Probes Tribal Woman Forced to Walk Naked" by Subir Bhaumik (2010), at <http:// www.bbc.com/news/world-south-asia10938729>. See also "Paraded Naked News" (2016) by the NDTV, which offers a compilation of news from 2009 to 2016 on this kind of major punishment, at <http://www.ndtv.com/ topic/paraded-naked/news $>$.

${ }^{5}$ I would like to remind the reader that gender is a construction so when we refer to 'masculinity' we are not directly referring to men as both male and female sexes can construct feminine or masculine attributes/ values. Traditionalist and essentialist binary pairs of masculinity and femininity or man and woman do not consider gender a cultural construction. See Judith Butler's Gender Trouble (1990). 
${ }^{6}$ Devi's "Draupadi" is introduced by Gayatri C. Spivak in the collection Breast Stories (2010, first published 1997).

7 The term 'adivasi' literally refers to 'the first settlers of India'. 'Adi' means first and 'vasi' means people. For more information see for example Orissa, templos y tribus (2008) by Ana García-Arroyo.

8 With regard to the Ramayana, I am referring to the text by Valmiki and also by Tulsi Das, the two canonical versions, which sing the glories of the masculine heroes. In this way my intention is to differentiate them from the other multiple versions of 'Ramayanas' in regional or local languages that have not been translated into English and are not standardized. They are known as the 'other Ramayanas' or 'Sitayanas', because they narrate the story from the position of the female protagonist, Sita. Brahmanical patriarchy does not accept these other 'Ramayanas'. See: Historia de las mujeres de la India (2009) by Ana García-Arroyo. See also Nabaneeta Dev Sen's “Candravati Ramayana: Feminizing the Rama-Tale" (2000).

${ }^{9}$ For more details about how the English carried out their colonial invasions in the adivasi area of West Bengal and Orissa, and how these populations resisted them and how they continue resisting hegemonic power, see the article "Mujer adivasi: clama la memoria" by Ana García-Arroyo (2017).

10 Here I embrace both meanings of the word 'fabulously': 1) extremely pleasing and successful, and 2) "of the nature of a fable or myth", which is very appropriate here as both writers re-write the myth and also contest it.

\section{Works cited}

AsHCROF, Bill. 2001. Post-Colonial Transformation. London and New York: Routledge.

Beauvolr, Simone de. (1949) 1997. The Second Sex. London: Vintage.

BHAUMIK, Subir. 2010. "India probes tribal woman 'forced to walk naked'". BBC News Calcutta. <http://www.bbc.com/news/worldsouth-asia-10938729>. Accessed January 21, 2017.

BRook, Peter. 1989. The Mahabharata. USA, UK, France: Channel Four Television Co., The Brooklyn Academy of Music, Mahabharata Ltd., Les Productions du 3eme Stage.

Butler, Judith. 1990. Gender Trouble. London: Routledge.

Chakrabarty, Bidyut. 2015. Left Radicalism in India. London and New York: Routledge.

ChakravartI, Uma. 2003. Gendering Caste: Through a Feminist Lens. Calcutta: Mandira Sen for Stree.
Chakravarti, Uma. 2007. Everyday Lives, Everyday Histories. Beyond the Kings and Brahmanas of Ancient India. New Delhi: Tulika Books.

Coburn, Thomas B. 1992. Encountering the Goddess. Delhi: Sri Satguru Publications.

DeVI, Mahasweta. (1997) 2010. Breast Stories. Introd. G.C. Spivak. Calcutta: Seagull Books.

Divakaruni, Chitra Banerjee. 2008. The Palace of Illusions. New York: Random House.

García-Arroyo, Ana. 2008. Orissa, templos y tribus. Barcelona: Laertes.

García-Arroyo, Ana. 2009. Historia de las mujeres de la India. Barcelona: Laertes.

GarcíA-Arroyo, Ana. 2017. “Mujer adivasi: clama la memoria". Indialogs. Spanish Journal of India Studies (4): 131-149.

Goel, Savita. 2007. "Tribal Women in the Selected Works of Mahsweta Devi". Indian Women Writers: Critical Perspectives. New Delhi: Sarup and Sons: 203-210. 
KeAY, John. 2000. India. A History. London: HarperCollins.

Narayan, R.K. (1978) 2004. The Mahabharata. London: Vision Books.

“Paraded Naked News". 2016. NDTV. <http:// www.ndtv.com/topic/paraded-naked/news>. Accessed January 25, 2017.

RADHAKRISHNAN, Sarvepalli. 1989. Indian Philosophy Vol. 1. New Delhi: Oxford U.P.

SeN, Nabaneeta Dev. 2000. "Candravati Ramayana: Feminizing the Rama-Tale". In Bose, Mandakranta (ed.) Faces of the Feminine in Ancient, Medieval and Modern India. Oxford and New York: Oxford U.P.
Sharma, Usha. 2007. Indian Women. From Tradition to Modernity Vol 1. New Delhi: Vista International Publishing House.

SHIVA, Vandana. 1989. Staying Alive: Women, Ecology and Development. London: Zed Books.

SPIVAK, Gayatri C. 1987. In Other Worlds. London and New York: Routledge.

THAROOR, Shashi. 1989. The Great Indian Novel. London: Penguin.

Zupančıč, Metka. 2013. "Ethics of Wisdom and Compassion in the Novels by Chitra Banerjee Divakaruni". Asian Studies I (XVII): 105-117. 